\title{
Leadership styles of school principals and their multiple intelligences profiles: Any relationship?
}

\author{
Ghamrawi, Norma $\triangle$ \\ Faculty of Education, Lebanese University, Beirut, Lebanon(dr.norma_ghamrawi@hotmail.com)
}

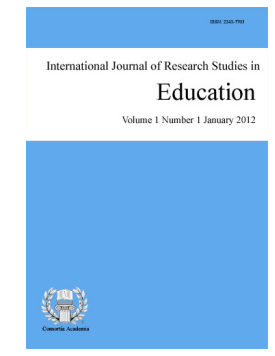

ISSN: $2243-7703$ Online ISSN: 2243-7711

OPEN ACCESS

\section{Abstract}

This study attempted to investigate any relationship existing between the leadership styles exhibited by Lebanese public school principals and their multiple intelligences profile. MLQ (5X) was employed to collect data relating to leadership styles of 307 school principals, and McKenzie (1999) was used to profile their multiple intelligences (MI). SPSS 18.0 was used to support data analysis. Results indicated that transformational leadership style was the dominant self-reported style exhibited by school principals. Visual-spatial intelligence was conveyed to be the intelligence enjoyed by the majority of school principals; followed equally by logical-mathematical and existential intelligences; then also equally by interpersonal and verbal-linguistic intelligences; followed by musical, intrapersonal, kinesthetic, and naturalist intelligences. Pearson correlation coefficients were calculated for the composite scores of MLQ and each individual MI. Strong positive correlations were detected between MI and existential, verbal and interpersonal intelligences. Linear Multiple Regression Analysis denoted that $47.5 \%$ of the total variance of transformational leadership was predicted by the interaction of the three MI (Existential, verbal, and Interpersonal), with existential intelligence being the strongest predictor of transformational leadership. Implications and suggestions for future research are provided.

Keywords: leadership styles; multiple intelligences; transformational leadership; transactional leadership; leadership development 


\section{Leadership styles of school principals and their multiple intelligences profiles: Any relationship?}

\section{Introduction}

The literature of school leadership has witnessed an unprecedented unanimity on the prominence of effective leaders in fostering school improvement (Harris, 2004; Hammersley-Fletcher \& Brundrett, 2005; Bush, 2008; Ghamrawi, 2011). In fact, studies from several countries across the globe have attributed successful school reform to effective school leadership (Ofsted, 2000; Leithwood \& Riehl 2003; Harris, 2004; Duignan, 2007; Harris \& Spillane, 2008; OECD, 2009; Ghamrawi, 2010). However, there is a broad range spectrum and multiplicity in describing effective school leadership. Thus, several labels for leadership appear in the literature, such as distributed leadership (Harris \& Spillane, 2008; Harris, 2004), including teacher leadership (Harris \& Townsend, 2007, Ghamrawi, 2010; 2011); transformational leadership (Burns, 1987; Leithwood \& Jantzi, 2000; Bass \& Riggio, 2005); instructional leadership (Hoy \& Hoy, 2009; Hallinger, 2007; Caldwell, 2006); participative or democratic leadership style (Lewin, 1939).

Long lists of descriptors of effective leaders can be derived from the massive literature of school leadership. Few of those qualities on the long list includes: strong communication skills (Lambert, 2005), ability to build effective human relationships with school staff (Leithwood \& Jantzi, 2005), visionary leadership (Parkes, 2004), remarkable knowledge of the self (West-Burnham, 2009), notable problem-solving skills (Kruger et al., 2007), and many others. The scrutiny of the previous attributes along with others that appear in the literature brings to the surface the concept of multiple intelligences (MI) introduced initially by Howard Gardner in his book Frames of Minds in 1983.

In fact, in the business management domain Riggio et al. (2002) assured that intelligence contributes to effective leadership. Also in the business management domain, Crainer and Dearlove (1999) convey a comparable manifestation, where they considered it essential for effective leaders to possess a plethora of skills, aptitudes, talents and abilities. Though these are findings generated in the business management domain, it is worth testing them in the education sector. This could be justified by the fact that many of the educational leadership concepts are business management notions that have crossed boarders, after a time lag, from their origination. Examples include Total Quality Management, Management by Objectives, and Turnaround (Peck \& Reitzug, 2012). Consequently, the purpose of this study was to examine the relationship between the leadership styles of school principals and their multiple intelligences profiles.

\subsection{Purpose of the study}

The purpose of the study was to investigate the applicability of a concept emergent in the business domain within the educational management domain. Thus it attempted to investigate any relationship existing between the leadership styles of school principals and their MI profiles. It strived to answer the following research questions:

a. What are the dominant leadership styles of school principals involved in the study?

b. Which MI prevail within the sample of school principals involved in the study?

c. What relationship exists between leadership styles of school principals and their MI?

d. Which is the fittest model composed of MI dimensions that predicts the transformational leadership style? 


\subsection{Importance of the study}

The existence of any relationship between the styles of leadership practice and the MI profiles exhibited by school leaders could be useful for leadership prediction and development of school principals for several reasons. First, as MI profiles are described in the literature to be dynamic and change from year to another as a function of the experiences that individuals get confronted with in their lives and careers; then consequently, this study could constitute additional evidence that leadership is buoyant and hence can be taught. This is specifically because Gardner (1993) argued that people are born with a given MI profile, yet they end up with different profiles at different stages of their lives.

Second, the enhancement of MI of school leaders or aspiring school leaders could be considered as a vital element in developing their leadership skills. This finding could be of some importance to professional development designers. In fact, the business management literature assures that organizational ineffectiveness has been attributed to futile leadership training tools which fails in supporting such organizations in selecting and developing leaders (Fiedler, 2001). Gardner's (1993) arguments support this point and go further to advocating MI theory as a significant tool allowing for extenuating overlooked talents, abolishing vacant or poorly occupied positions within organizations, and providing leaders with skill sets that supports them in facing challenges related to their positions.

\section{Review of related literature}

\subsection{Leadership styles}

The characteristic approach to leadership practice displayed by a leader, particularly to the manner he/she interacts with subordinates within the school context is referred to as leadership style (Fertman \& ven Linden, 1999). Several leadership styles theories are detailed in the literature of educational leadership such as that of Lewin (1939) who distinguishes three styles of leadership practice which include: authoritarian or autocratic style, democratic or participative style, and laissez-faire or passive style. Authoritarian leaders do not involve any school members in the decisions they take. On the other end of the continuum, laissez-faire leaders leave decision-making for school members without any interference on their behalf. In between the two styles, democratic leaders collaborate with their staff in all school activities including decision-making.

Another set of leadership styles was introduced by Likert (1967) who identified four main styles of leadership focusing on the degree to which subordinates are involved in decision-making. These include exploitive authoritarian style, benevolent authoritative style, consultative style, and participative style. On a continuum, if the exploitive authoritarian style comes on one end, then at the other end lays the participative style with which leaders are quite close to their subordinates, listen well to them and involve them in decision-making. In between comes the benevolent authoritative style through which leaders use rewards to encourage performance and listens more to subordinates' concerns and ideas, yet decision-making continues to be central and made only by themselves. Next is the consultative style through which leaders make genuine efforts to involve subordinates in decision-making.

The most popular leadership styles theory receiving a lot of citation and debate in the literature is that of Burns (1978). Building on earlier theories, Burns (1978) introduced transactional, transformational leadership styles. Transactional leadership is an exchange process whereby leaders gain compliance of subordinates through rewards for performance or punishment for the lack of it (Bass \& Avolio, 2004). They do not practice leadership unless problems arise even though they might set standards (passive management-by-exception); or avoid any risks and hence set standards and monitor details (active management-by-exception); or set standards and communicate them, exchange rewards, provide feedback and praise to followers when need be (constructive transactional leader) (Bass, 1985). 
Ghamrawi, N.

Transformational leadership is visionary whereby leaders set and communicate vision with which they engender intense emotions in subordinates. They utilize a blend of trust and empowerment so as to render such a vision owned by followers and thus fight for fulfilling it (Carlson, 1996). Transformational leaders are motivating, influential, role models and pro-active (Bass \& Avolio, 2004). They cater for individuals (individual consideration); trigger thinking in new modes (intellectual consideration); communicate high expectations (inspirational motivation); and model behaviors themselves (idealized influence) (Bass, 1985). Transformational and transactional leaders are compared in table 1.

\section{Table 1}

Transformational versus Transactional leaders

\begin{tabular}{ll}
\hline Transactional Leader & Transformational Leader \\
\hline Burns (1978), Bass (1985), Carlson (1996), and Bass and Avolio (2004) \\
\hline Reactive & Proactive \\
Creates structures and processes for control & Creates a climate of trust \\
Sets goals to obtain immediate results & Establishes long-term vision \\
Solves problems & Empowers individuals so that they may solve arising \\
& problems \\
Secures the culture & Challenges the culture \\
Sets rules for other to follow & Coaches and develop people's potentials \\
Maintains a situation and attempts to improve it & Changes the whole situation when needed \\
Power springs out of his/her position & Power springs out of his/her influential character \\
\hline
\end{tabular}

Though many studies in the literature advocated transformational leadership, Bass (1998) believes that both styles are complementary and that it is important for effective leaders to exhibit both and be able to practice any one of them as need be. This is parallel to Bass and Avolio (1994) who argue that both styles are needed for different situations and that each leader needs to know when to display a particular approach.

\subsection{Multiple Intelligence Theory (MIT)}

Gardner (1983) introduced a revolutionary theory with which he rejected the unitary concept of intelligence and endorsed a more inclusive definition of intelligence that is based on human aptitudes that have long been neglected in the education domain. So he proposed that humans enjoy a spectrum of talents which constitute their MI profiles. Initially he proposed seven types of intelligences which included: verbal-linguistic, logical-mathematica1, visual-spatial, musical-rhythmic, bodily-kinesthetic, interpersonal, and intrapersonal. Believing that new intelligences can be unveiled later on (Gardner, 1983), he proposed his eighth intelligence 'naturalist intelligence and then his ninth intelligence 'spiritual intelligence' (Gardner, 1999). It should be noted that Gardner (2006) manifests that he never meant to target the education domain with his MI theory initially. However, it became mostly popular among educators (Gardner, 2006).

Synonyms of the MI are as follows: verbal-linguistic or word smart; logical-mathematica1 or number smart; visual-spatial or picture smart; musical-rhythmic or music smart; bodily-kinesthetic or body smart; interpersonal or people smart; and intrapersonal or self-smart; naturalistic or nature smart; spiritual or faith smart. Armstrong (1994) illustrates that MI profiles are very unique, just like finger prints. So, though all humans enjoy all MI, their MI are not developed exactly and identically to the same degree at the same time. Some intelligence may be stronger than others and a given intelligence may be enhanced and developed over time with new experiences and opportunities for learning.

\subsection{Leadership and MI}

Gardner (1999) argued, without any empirical data, that leaders like other human beings exhibit several multiple intelligences. Yet the most dominating intelligences they enjoy are the verbal-linguistic, interpersonal, and intrapersonal intelligences (p. 128). In other words, leaders are articulate and expressive; and demonstrate a 
strong sense of their own selves. One study in Business Management domain conducted by Hoffman and Frost (2006) examined the impact of emotional, social, and cognitive intelligences on the dimensions of transformational leadership. Their findings indicated that a multiple intelligences framework is a useful approach to predict transformational leadership. Recently, Riggio, Murphy, and Pirozzolo (2013) concluded that the possession of multiple forms of intelligence is important for effective leadership; the incorporation of multiple intelligences constructs into existing leadership theories will improve the understanding of effective leadership; and that the research on multiple intelligences has important implications for both the selection and training of future leaders. Hebert (2011) investigated the relationship between transformational leadership and emotional intelligence. Her results indicated a strong positive correlation. Likewise, Hamidi, and Azizi (2012) also investigated the relationship between transformational leadership and emotional intelligence and arrived into similar findings as Hebert (2011).

\section{Methodology}

This study is quantitative correlational in nature that relies on positivist knowledge claims and utilizes two pre-determined survey instruments to yield statistical data. Instruments were employed as inquiry tools to distinguish any relationship between MI profiles and leadership styles of school principals. The basic advantage of utilizing correlational research method is that "it permits the relationships [to be analyzed] among a large number of variables in a single study" (Gall et al., 1996, p. 414).

\subsection{Instrument}

This study is based on the theoretical framework of leadership styles of Burns (1978) and Garner's (1999) multiple intelligences theory. So, two pre-determined instruments were employed to collect data for this study. Avolio and Bass (1992) Multifactor Leadership Questionnaire (MLQ - 5X) was employed in order to identify principals' leadership styles. It is grouped on three styles i.e. Transformational Leadership, Transactional Leadership and Passive/Avoidant Behavior. The reliability of McKenzie's (1999) adapted version was assessed through a pilot study from a sample of 63 teachers conducted by the same author, yet in another study within the same context in two schools. Results indicated that all subscales do have internal consistency with Cronbach's alphas of .81 (laissez-faire), 0.80 (passive management-by-exception), and 0.82 (contingent reward), 0.89 (active management-by-exception), 0.88 (individualized influence-attributes), 0.81 (individualized influence-behaviors), 0.80 (inspirational motivation), 0.85 (intellectual stimulation), and 0.81 (individualized consideration).

On the other hand, an adapted version of McKenzie's (1999) multiple intelligences survey was employed to derive MI profiles for principals involved in the study. The reliability of McKenzie's (1999) adapted version was assessed through a pilot study from a sample of 39 teachers conducted by the same author, yet in another study within the same context in three schools. Results indicated that all subscales do have internal consistency with Cronbach's alphas of 0.80 (logical intelligence), 0.88 (interpersonal intelligence), and 0.89 (intrapersonal intelligence), 0.79 (visual intelligence), 0.81 (musical intelligence), 0.76 (kinesthetic intelligence), 0.80 (existential intelligence), 0.82 (verbal intelligence), and 0.81 (naturalist intelligence).

Thus the survey administered to school principals consisted of three sections. The first attempted to derive demographic information about participants; the second addressed their leadership styles; and the third attended to their MI profiles. The survey was administered in Arabic. Both Arabized survey instruments were previously prepared, adapted, piloted and employed in separate studies by the same researcher with in the same educational context.

\subsection{Participants}

1178 copies; corresponding to the total number of public school principals in Lebanon- D-RASATI (2011), of the survey were prepared and placed in a sealed envelope along with a cover sheet detailing the purpose of the study and the contact information of the researcher; and an informed consent form. During an assembly held at 
Ghamrawi, N.

the Lebanese Ministry of Education and Higher Education for all public school principals, the 1178 copies of the survey were made available for distribution. Only 899 copies were distributed due to absence of some principals, the early departure of others and the refusal of few of them to take the envelope. The cover sheet indicated that principals could return back the completed surveys through one of four methods: (1) mail it back to the author; (2) fill it online through 'survey monkey' (details of how to log in and complete it were given); (3) fax it back to the researcher; or (4) call the researcher who would send somebody to pick it from school in case that was possible, depending on school location. Consequently, the number of returned surveys was 378 and were received mainly through mail $(73 \%)$, followed by fax $(19 \%)$, then online completion $(6 \%)$ and least were received by collection from schools $(2 \%)$. Of the 378 questionnaires received, only 307 were completely filled and were thus useful for the research study. In other words, almost a quarter of the total population of public school principals $(26 \%)$ was involved in this study.

\subsection{Data analysis}

Both survey data were processed using SPSS 18.0. Descriptive statistics were used to describe and summarize the properties of the mass of data collected from school principals. Mean scores, standard deviations and percentages were calculated per each item of both survey instruments. Pearson correlation coefficients were calculated for the composite scores of MLQ and each MI. Linear Multiple Regression Analysis was carried out in order to detect the strongest predictor(s) of transformational leadership.

\section{Results}

\subsection{Demographics information}

Based on table 2, female participants $(54.9 \%)$ in this study outweigh male respondents (45.1\%). Almost half (47.6\%) of the principals involved in the study were 46 years old or more. They are mostly concentrated in Area 1 (Beirut Governorate) which constitutes the capital of the country and the majority (51.0\%) has been occupying leadership positions since over 10 years. Moreover, around 75\% of participants were holders of Bachelor's degrees obtained in domains other than education. Interestingly, 7.2\% did not hold university degrees and none were holders of any Masters or $\mathrm{PhD}$ degrees. Finally, $78.2 \%$ of principals involved in the study received a two-year leadership training prior to their involvement in this study through the Leadership Development Program (LDP). LDP is an initiative of the Lebanese Ministry of Education and Higher Education (MEHE) and funded by the World Bank in the form of a loan entitled: "Education Development Program" (EDP).

Table 2

Demographic characteristics of participants

\begin{tabular}{|c|c|c|}
\hline & Items & $\%$ \\
\hline \multicolumn{3}{|l|}{ Gender } \\
\hline Male & & 45.1 \\
\hline Female & & 54.9 \\
\hline \multicolumn{3}{|l|}{ Age (Years) } \\
\hline Less than 25 & & 1.9 \\
\hline $26-35$ & & 11.6 \\
\hline $36-45$ & & 38.9 \\
\hline 46 and above & & 47.6 \\
\hline
\end{tabular}


Table 2... continuation

Demographic characteristics of participants

\begin{tabular}{ll}
\hline \multicolumn{1}{c}{ Items } & $\%$ \\
\hline Geographical Distribution & $38.1 \%$ \\
Area 1 (Beirut Governorate) & $22.9 \%$ \\
Area 2 (Mount Lebanon Governorate) & $12.5 \%$ \\
Area 3 (Northern Lebanon Governorate) & $6.2 \%$ \\
Area 4 (Bekaa Governorate) & $7.9 \%$ \\
Area 5 (Southern Lebanon Governorate) & $2.4 \%$ \\
Area 6 (Nabatieh Governorate) & \\
Experience in Principalship (Years) & 12.4 \\
Less than 4 & 11.9 \\
5-9 & 30.1 \\
10- 14 & 20.9 \\
15- 19 & 24.7 \\
20 and above & \\
Highest Degree Held & 7.2 \\
End of School Certificate or less & 18.3 \\
Bachelors (Faculty of Education Graduates) & 74.5 \\
Bachelors (Graduated from faculties other than Education) & 0.0 \\
Masters & 0.0 \\
PhD & \\
Previous Enrollment in Leadership Development Program (LDP) & \\
Subjected to LDP & 21.8 \\
Not subjected to LDP & \\
\hline
\end{tabular}

The comparison of the sample against the distribution of school principals across the country reflects that in terms of geographical distribution, the sample is not representative of the total population of public schools across Governorates as shown in table 3.

Table 3

Comparison of the geographical distribution

\begin{tabular}{lll}
\hline Governorate & Population Distribution* & Sample Distribution \\
\hline Beirut & $5.1 \%$ & $38.1 \%$ \\
Mount Lebanon & $21.5 \%$ & $22.9 \%$ \\
North & $33.6 \%$ & $12.5 \%$ \\
Bekaa & $18.0 \%$ & $6.2 \%$ \\
South & $11.9 \%$ & $7.9 \%$ \\
Nabatieh & $10.0 \%$ & $2.4 \%$ \\
Total & $100 \%$ & $100 \%$ \\
\hline Note. Data obtained from D-RASATI (2011), Field Survey Results Report of Lebanese Public Schools. \\
Lebanese Ministry of Education and Higher Education.
\end{tabular}

\subsection{Research question 1: What are the dominant leadership styles of school principals involved in the study?}

Data utilized to respond to the above research question was derived from the MLQ survey. The mean scores of the three categories of leadership styles were computed along with means for their corresponding sub-styles. This was carried out by adding scores for all responses of a scale's items and dividing them by the total number of responses for that item. Results of this analysis are presented in table 4. Wherein, the dominant leadership style exhibited by school principals involved in the study is the transformational leadership style, followed by transactional leadership style and last by passive or avoidant style. 
Ghamrawi, N.

Table 4

Means of leadership styles

\begin{tabular}{llll}
\hline Leadership Styles & Sub-styles & $\begin{array}{l}\text { Means of } \\
\text { Sub-styles }\end{array}$ & $\begin{array}{l}\text { Composite Score } \\
\text { per Category }\end{array}$ \\
\hline Passive or Avoidant & Laissez-faire & 0.63 & 1.245 \\
& Passive management-by-exception & 1.86 & 3.065 \\
Transactional & Contingent reward & 3.12 & 3.115 \\
\multirow{5}{*}{ Transformational } & Active management-by-exception & 3.01 & \\
& Active management-by-exception & 2.96 & \\
& Individualized influence (attributes) & 3.45 & \\
& Individualized influence (behaviors) & 3.12 & \\
& Inspirational motivation & 2.99 & \\
& Intellectual stimulation & 2.96 & 3.21 \\
\hline
\end{tabular}

\subsection{Research question 2: Which MI prevail within the sample of school principals involved in the study?}

Data collected using McKenzie's (1999) survey is presented in table 5 which displays the scores per each MI obtained for the sample on a scale of one to ten. Visual-spatial intelligence tops the list of intelligences enjoyed by school principals involved in the study. This is followed equally by logical-mathematical and existential intelligences; then also equally by interpersonal and verbal-linguistic intelligences; followed by intrapersonal intelligence; musical intelligence; kinesthetic intelligence; and finally naturalist intelligence.

Table 5

Average mean scores of MI obtained for the sample on individual MI

\begin{tabular}{llll}
\hline Multiple Intelligences & Mean Score & Percentage & Standard Deviation \\
\hline Logical & 8.23 & $82.3 \%$ & 0.212 \\
Interpersonal & 6.01 & $60.1 \%$ & 0.116 \\
Intrapersonal & 7.02 & $70.2 \%$ & 0.134 \\
Visual & 9.04 & $90.4 \%$ & 0.312 \\
Musical & 5.99 & $59.9 \%$ & 0.262 \\
Kinesthetic & 2.98 & $29.8 \%$ & 0.415 \\
Existential & 8.03 & $80.3 \%$ & 0.327 \\
Verbal & 7.02 & $70.2 \%$ & 0.158 \\
Naturalist & 1.97 & $19.7 \%$ & 0.265 \\
\hline
\end{tabular}

\subsection{Research question 3: What relationship exists between leadership styles of school principals and their MI?}

Pearson correlation coefficients were calculated for the composite scores of MLQ and each MI. The correlation matrix is presented in table 6 . As table 6 indicates, significant positive correlations have been obtained between transformational leadership and many of the MI. A positive significant correlation has been obtained between transformational leadership and logical-mathematical intelligence $(\mathrm{r}=.556, \mathrm{p}<.01)$; interpersonal intelligence $(\mathrm{r}=.519, \mathrm{p}<.01)$; intrapersonal intelligence $(\mathrm{r}=.565, \mathrm{p}<.01)$; visual-spatial intelligence $(\mathrm{r}=.565, \mathrm{p}<.01)$; existential intelligence $(\mathrm{r}=.991, \mathrm{p}<.01)$; and verbal-linguistic intelligence $(\mathrm{r}=.811 ; \mathrm{p}<.01)$. No correlation between transformational leadership and musical, kinesthetic and naturalist intelligences have been noted.

Positive significant correlation between transactional leadership and logical-mathematical intelligence $(\mathrm{r}=.273, \mathrm{p}<.01)$; interpersonal intelligence $(\mathrm{r}=.321, \mathrm{p}<.01)$; and verbal-linguistic intelligence $(\mathrm{r}=.321 ; \mathrm{p}<.01)$. No correlation between transactional leadership and other intelligences have been noted. Negative correlations have 
been obtained between the Passive/Avoidant style of leadership and types of the intelligences: logical-mathematical $(\mathrm{r}=-.448, \mathrm{p}<.01)$; Intrapersonal $(\mathrm{r}=-.352, \mathrm{p}<.01)$, Interpersonal $(\mathrm{r}=-.402, \mathrm{p}<.01)$; visual-spatial $(\mathrm{r}=-.402, \mathrm{p}<.01)$; musical $(\mathrm{r}=-.382, \mathrm{p}<.01)$; kinesthetic $(\mathrm{r}=-.479, \mathrm{p}<.01)$; existential $(\mathrm{r}=-.477$, $\mathrm{p}<.01)$; verbal-linguistic $(\mathrm{r}=-.352, \mathrm{p}<0.01)$; and naturalist $(\mathrm{r}=-.402, \mathrm{p}<.01)$.

Table 6

Correlation matrix between Leadership Styles and MI

\begin{tabular}{|c|c|c|c|c|c|c|c|c|c|}
\hline \multirow[t]{2}{*}{ Multiple Intelligences } & \multicolumn{2}{|c|}{$\begin{array}{l}\text { Transformational } \\
\text { Style }\end{array}$} & \multirow[t]{2}{*}{ Leadership } & \multicolumn{2}{|c|}{$\begin{array}{l}\text { Transactional } \\
\text { Style }\end{array}$} & \multirow[t]{2}{*}{ Leadership } & \multicolumn{3}{|c|}{ Laissez-faire Leadership Style } \\
\hline & 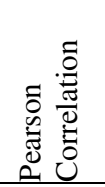 & 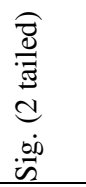 & & E & 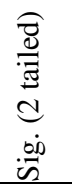 & & 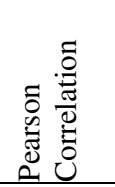 & 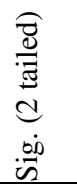 & Z \\
\hline Logical & $.516 * *$ & .000 & 307 & $.273 * *$ & .006 & 307 & $-.477 * *$ & .000 & 307 \\
\hline Interpersonal & $.669 * *$ & .000 & 307 & $.321 * *$ & .001 & 307 & $-.352 * *$ & .000 & 307 \\
\hline Intrapersonal & $.515^{* *}$ & .000 & 307 & .287 & .064 & 307 & $-.402 * *$ & .000 & 307 \\
\hline Visual & $.565 * *$ & .000 & 307 & .179 & .074 & 307 & $-.402 * *$ & .000 & 307 \\
\hline Musical & .111 & .052 & 307 & .159 & .111 & 307 & $-.382 * *$ & .000 & 307 \\
\hline Kinesthetic & .164 & .071 & 307 & .179 & .072 & 307 & $-.479 * *$ & .000 & 307 \\
\hline Existential & $.991 * *$ & .000 & 307 & .321 & .061 & 307 & $-.477 * *$ & .000 & 307 \\
\hline Verbal & $.811 * *$ & .000 & 307 & $.321 * *$ & .001 & 307 & $-.352 * *$ & .000 & 307 \\
\hline Naturalist & .159 & .060 & 307 & .179 & .561 & 307 & $-.402 * *$ & .000 & 307 \\
\hline
\end{tabular}

\subsection{Research question 4: Which is the fittest model composed of MI dimensions that predicts the}

transformational leadership style?

In order to identify the fittest MI model in predicting transformational leadership, Linear Multiple Regression Analysis was performed, the model being composed of the three MI with the highest magnitudes: Existential, verbal-linguistic, and interpersonal intelligences $\left(\mathrm{R}^{2}=.457, \mathrm{~F}=29.20, \mathrm{p}<.01\right)$ (Table 7). It was found that existential intelligence was the strongest predictor of transformational leadership $(\beta=.310, p<.01)$, followed by verbal-linguistic $(\beta=.308 . p<.01)$, and interpersonal intelligence $(\beta=.214, p<0.5) .47 .5 \%$ of the total variance of transformational leadership is predicted by the interaction of the three MI (Existential, verbal, and Interpersonal).

Table 7

Model for predicting transformational leadership

\begin{tabular}{lllllll}
\hline Model & $\mathrm{R}$ & R Square & $\begin{array}{l}\text { Adjusted R } \\
\text { Square }\end{array}$ & $\begin{array}{l}\text { Std Error of } \\
\text { the Estimate }\end{array}$ & F & Sig. \\
\hline $\begin{array}{l}\text { Existential } \\
\begin{array}{l}\text { Verbal } \\
\text { Interpersonal }\end{array}\end{array}$ & .689 & .475 & .458 & .226 & 29.20 & .000 \\
\hline
\end{tabular}

Table 8

Beta coefficients for the model predicting transformational leadership

\begin{tabular}{llllll}
\hline Model & $\begin{array}{l}\text { Unstandardized } \\
\text { Coefficients }\end{array}$ & \multicolumn{3}{c}{$\begin{array}{l}\text { Standardized } \\
\text { Coefficients }\end{array}$} & $\mathrm{t}$ \\
\cline { 2 - 4 } & $\mathrm{B}$ & Std. Error & \multicolumn{1}{l}{ Beta } & \\
\hline (Constant) & .191 & .349 & .549 & .584 \\
Existential & .016 & .005 & .310 & 3.017 & .003 \\
Verbal & .014 & .004 & .308 & 3.457 & .001 \\
Interpersonal & .007 & .003 & .214 & 2.319 & .022 \\
\hline
\end{tabular}




\section{Discussion and suggestions for future research}

The most dominant leadership style in the Lebanese public school system is transformational leadership. More accurately, as Avolio and Bass (1995) argue, principals were 'more transformational' and 'less transactional'. This is a very interesting finding because the majority of school principals involved in the study was previously enrolled in the Leadership Development Program (LDP), secured by the Lebanese Ministry of Education and Higher Education. Within the same context, Yaacoub (2000) concluded in his study that Lebanese public school principals exhibited almost no room to practice leadership. He even considered principals of the public school sector to be acting out as school keepers rather than school leaders. Thus this study indicates a shift in the self-perceived leadership style of public school principals, mainly towards transformational leadership. Such a shift may be attributed to LDP, however, confirmation or negation remains a function of future research.

Visual-spatial intelligence tops the list of intelligences enjoyed by school principals involved in the study. This finding goes parallel to Armstrong (1994) who claims that almost 90\% of humans are visual learners. Visual-spatial people are gifted with the ability to visualize the world more accurately (Armstrong, 1994). They can re-create an idea into a working visual model or a mental map; and provide a strong sense of spatial awareness for where they are positioned in relation to the world around them (Armstrong, 1994). How such skills attributed to visual- spatial learners impede transformational leadership skills remains an important research question that can be addressed in future research.

Logical-mathematical and existential intelligences equally rank the second among the list of MI enjoyed by school principals involved in the study. Logical-mathematical intelligence entails aptitudes in scientific and mathematical reasoning. It is defined as the ability to appreciate and calculate the effect of actions upon objects or ideas and the relationships among them; to apply inductive and deductive reasoning skills; to provide solutions and to overcome complex mathematical and logical challenges as well as solving critical and creative problems (Armstrong, 2009). Most, if not all of the previous features are basic ingredients of effective leadership according to the literature (Ghamrawi, 2006). On the other hand, people characterized with strong existential intelligence often question themselves about the meaning of life, the intricacies of existence and they usually provide answers to these fundamental questions (Gardner, 1997). Gardner (1997) argues that such people are more likely to apply and transport this meaningfulness at work, which in turn results in increased levels of motivation and sense of well-being that not only impact one's self but goes beyond that to affect subordinates. Motivating workers and improving their sense of well-being has also been considered by several studies in the literature as important elements of effective leadership (Ghamrawi, 2006). In other words, the skills attributed to logical-mathematical and existential intelligences seem to overlap with those ascribed to effective leaders. Future research is supposed to address this particular aspect especially that both existential intelligence has been determined to be a strong predictor of transformational leadership.

Third on the list of MI enjoyed by participant principals, comes equally interpersonal and verbal-linguistic intelligences, both of which have been determined to be strong predictors of transformational leadership within this study. Interpersonal intelligence enables its owner to connect establish rapport quickly and easily with others. They tend to make people feel at ease; read others' reactions; empathize; and invite people to trust them and respect them (Armstrong, 1994). Such skills of interpersonal intelligence have been enlisted among the list of effective leadership practice according to the literature (Ghamrawi, 2006). On the other hand, verbal-linguistic people are ones who reflect mastery of the art of communication with others. According to Armstrong (1994), verbal-linguistic people demonstrate skills of listening to others, ability to explain their view points, persuade others, sell, argue and speak publically. Again many of these skills have been attributed to effective leaders according to the literature (Ghamrawi, 2006). Future research is encouraged to tackle the inter-relationship between verbal-linguistic and interpersonal intelligences and how they relate to transformational leadership.

Intrapersonal intelligence comes next on the list of MI enjoyed by participant principals, followed by musical intelligence, then kinesthetic intelligence and finally by naturalist intelligence. Though none of these 
intelligences has been reported to be a predictor of transformational leadership in this study, many of the skills attributed to their owners are also attributed to effective leadership skills according to the literature. For example, intrapersonal people have good knowledge of the self (Gardner, 2006); musical people are sensitive and self-controlled (Armstrong, 1994); kinesthetic people are able to use body language effectively (Armstrong, 1994); and naturalist people are culturally sensitive (Armstrong, 1994).

\section{Conclusions and recommendations for practice and theory}

The findings of this study indicate that multiple intelligences can act as one venue for improving, enhancing and promoting effective leadership skills. Multiple intelligences are fluid in nature and are very similar to finger prints: no two individuals may have the same MI profile (Armstrong, 1994). Thus multiple intelligences can serve as a practical and down-to-earth approach to differentiating leadership skills acquisition, within leadership development initiatives. The same way differentiated instruction is highly preferred as an approach to learning and teaching in classrooms as it maximizes the learning potential of students; differentiating the routes for acquiring leadership skills is equally valued as it offers a plethora of techniques for school principals and even other staff to develop their leadership capacity. Each individual can be provided with the leadership development that is tailored to his needs and preferences as opposed to the 'one-size-fits-all' approach in leadership training. Training would then be responsive to unique training needs of individual school principal, to maximize the skills of each school principal, and thus enhances organizational productivity.

Special attention should be given to verbal-linguistic, interpersonal and existential intelligences; as these intelligences have been reported to be strong predictors of transformational leadership. Though more research, preferably qualitative in nature is needed to understand this relationship, some arguments can be made. In fact, based on the literature of multiple intelligences, together verbal-linguistic and interpersonal intelligences constitute an important framework for establishing superb rapport with sub-ordinates or colleagues; empathizing with them; listening to them; acting appropriately according to their needs; understanding their feelings, moods and motives; and persuading and influencing them through effective communication skills (Armstrong, 1994). With this brief list of the skills attributed to individuals characterized by these two kinds of intelligences, and with the strong correlation obtained for these with transformational leadership; it may be argued that a quantum leap with transformational leadership skills can be made with the development of these intelligences.

Finally, the finding pertaining to existential intelligence is one that has the potential to open the gate to a lot of debate. It should be noted that existential intelligence has received and still receives a lot of debate as to whether it can be considered as one form of human intelligences. Such a debate was initiated by Gardner himself (Gardner, 1999). Accepting existential intelligence as one form of the multiple intelligences, many arguments can be made based on the findings of this study. Existential people are described as being authentic individuals who make their choices whilst fully aware of consequences on their own selves, others, and to always act to maximize the dignity, integrity and accomplishments of all (Branson, 2006). They are able to "cultivate optimal change, creativity, common cause, and optimal actualization of opportunity" (Spreitzer et al., 2000, p. 13). Gardner (1999) argues that leaders who are able to address existential questions are the expected to be quite effective in motivating and mobilizing people. That is to say existential intelligence could support sub-ordinates by providing them with a sense of purpose and an inspirational vision based on values and beliefs thus creating an ethos that can pervade the whole organization. Through this channel in particular, it can be argued that existential intelligence could leave positive impact on the acquisition of transformational leadership skills. Future research would be necessary to understand thoroughly this relationship.

\subsection{Limitation of the study}

This study investigated the relationship existing between leadership styles of school principals and their Multiple Intelligences profiles quantitatively. No qualitative data were available so as to earn plural empathetic understanding of this relationship. As such, the study confirms a relationship between the two investigated 
Ghamrawi, N.

factors; it does not suggest why those two factors are interdependent. It would be very useful for future research to examine such a relationship using qualitative data. On the other hand, the MLQ was completed by school principals themselves. This could present a potential bias to the derived data. It would be useful to have the MLQ forms completed also by school teachers thus collect data about the leadership styles of such principals as perceived by their teachers. This would avoid any bias.

\section{References:}

Armstrong, T. (1994). Multiple intelligences in the classroom. Alexandra, VA: Association for Supervision and Curriculum Development.

Armstrong, T. (2009). Multiple intelligences in the classroom (3rd ed.). Alexandria, VA: Association for Supervision and Curriculum Development.

Avolio, B., \& Bass, B. (2004).Multifactor leadership questionnaire (3rd ed.). Mind Garden.

Bass, B. (1985). Leadership and performance beyond expectations. New York: The Free Press.

Bass, B. M., \& Riggio, E. R. (2005). Transformational leadership. Psychology Press: New Jersey.

Bass, B., \& Aviolo, B. (1992). Multifactor leadership questionnaire-Short form 6S. Retrieved October 16, 2011, from http://www.uwec.edu/Ssow/Meares/Leadership-MLQ.htm

Branson, C. (2006). Beyond authenticity: Contemporary leadership from a worldview perspective. Value and Ethics, 4(4), 1-7.

Burns, J. (1978). Leadership. New York: Harper \& Row.

Bush, T. (2008). Leadership and management development in education. London: Sage.

Caldwell, B. J. (2006). Re-imagining educational leadership. Camberwell: ACER Press.

Carlson, R. (1996). Reframing and reform: Perspectives on organization, leadership, and school change. White Plains: Longman.

Center of Educational Research and Development [CERD] (2010). Annual schools report 2009-2012. Retrieved from: http://www.crdp.org/CRDP/Arabic/ar-statistics/a_schoolguide.asp

Crainer, S., \& Dearlove, D. (1999, July). Death of executive talent [electronic version]. Journal of Management Review, 88(7), 16-23.

Developing Rehabilitation Assistance to Schools and Teacher Improvement (D-RASATI) (2011). Field survey results report of Lebanese public schools. Lebanese Ministry of Education and Higher Education.

Duignan, P. (2007). Address to catholic education conference. Sydney, Australia.

Fertman, C. I., \& van Linden, J. A. (1999). Character education: An essential ingredient for youth leadership development. NASSP Bulletin, 83(609), 9-15. http://dx.doi.org/10.1177/019263659908360902

Fiedler, F. E. (2001). When IQ + experience = performance. Journal of Leadership and Organizational Development, 22(3), 132-143. http://dx.doi.org/10.1108/01437730110389283

Gall, M. D., Gall, J. P., \& Borg, W. R. (Eds.). (1996). Educational research: An introduction (4 ${ }^{\text {th }}$ ed.). New York: Pearson Education.

Gardner, H. (1983). Frames of Mind: The theory of multiple intelligences. New York: Basic Books.

Gardner, H. (1993). Multiple intelligences: The theory in practice. New York: Basic Books.

Gardner, H. (1999). Intelligence reframed. New York: Basic Books.

Gardner, H. (2006). Multiple Intelligences: New Horizons. New York: Basic Books.

Ghamrawi, N. (2006). Investigating teacher leadership in three private K-12 schools in Beirut, Lebanon (Unpublished doctoral thesis). University of Leicester, UK.

Ghamrawi, N. (2010). No teacher left behind: subject leadership that promotes teacher leadership. Educational Management Administration \& Leadership, 38(3), 304-320. http://dx.doi.org/10.1177/1741143209359713

Ghamrawi, N. (2011). Trust me. Your school can do better-A message from teachers to principals. Educational Management Administration \& Leadership, 39(3), 333-348. http://dx.doi.org/10.1177/1741143210393997

Hallinger, P. (2007). Research on the practice of instructional and transformational leadership: Retrospect and 
Leadership styles of school principals and their multiple intelligences profiles: Any relationship?

prospect. Retrieved from

http://www.cmmu.mahidol.ac.th/adminsystem/file_NEWS_document/Acer_Paper_Final.pdf

Hammersley-Fletcher, L., \& Brundrett, M. (2005). Leaders on leadership: The impressions of primary school head teachers and subject leaders. School Leadership and Management, 25(1), 59-75.

http://dx.doi.org/10.1080/1363243052000317064

Harris, A. (2004). Distributed leadership and school improvement: Leading or misleading? Educational Management and Administration, 32(1), 11-24.

Harris, A., \& Spillane, J. (2008). Distributed leadership through the looking glass. Management in Education, 22(1), 31-34. http://dx.doi.org/10.1177/0892020607085623

Harris, A., \& Townsend, A. (2007). Developing leaders for tomorrow: Releasing system potential. School Leadership and Management, 27(2), 167-177. http://dx.doi.org/10.1080/13632430701237339

Hoffman, B. J., \& Frost, B. C. (2006). Multiple intelligences of transformational leaders: An empirical examination. International Journal of Manpower, 27(1), 37-51. http://dx.doi.org/10.1108/01437720610652826

Hoy, A. W., \& Hoy, W. K. (2009). Instructional leadership: A research-based guide

Kruger, M., Witziers, B., \& Sleegers, P. (2007). The impact of school leader variables on school level factors: Validation of a causal model. School Effectiveness and School Improvement, 18(1), 1-20. http://dx.doi.org/10.1080/09243450600797638

Lambert, L. (2005). Leadership for lasting reform. Educational Leadership, 62(5), 62-65.

Leithwood, K., \& Jantzi, D. (2000). Principal and teacher leader effects: A replication. School Leadership and Management, 20(4), 415-434. http://dx.doi.org/10.1080/713696963

Leithwood, K., \& Jantzi, D. (2005). Tranformational leadership. In B. Davies (Ed.), The essentials of school leadership (pp.31-43). London: Paul Chapman.

Leithwood, K., \& Riehl, L. (2003). What we know about successful school leadership. Nottingham: National College for School Leadership.

Lewin, K., Lippit, R., \& White, R. (1939). Patterns of aggressive behavior in experimentally created social climates. Journal of Social Psychology, 10, 271-301. http://dx.doi.org/10.1080/00224545.1939.9713366

Likert, R. (1967). The human organization: Its management and value. New York: McGraw-Hill.

McKenzie, W. (1999). Multiple intelligence survey. Retrieved from http://surfaquarium.com/MI/inventory.htm

OECD. (2009). Creating effective teaching and learning environments: First results from TALIS. Paris: OECD.

Ofsted. (2000). Improving city schools: Strategies to promote educational inclusion. London: Ofsted.

Parkes, S. (2004). Values underpinning effective principalship. An observational study of effective principals in action in a selection of NSW secondary schools. NSW Department of Education and Training. Retrieved from: http://www.aspa.asn.au/confs/Aspa2004/parkes.ppt

Peck, C., \& Reitzug, U. C. (2012). How existing business management concepts become school leadership fashions. The Journal of Leadership for Effective and Equitable Organizations, 48(2), 347-381.

Riggio, R. E., Murphy, S. E., \& Pirozzolo, F. (2002). Multiple intelligences and leadership. Mahwah, NJ: Lawrence Erlbaum Associates.

Riggio, R. E., Murphy, S. E., \& Pirozzolo, F. (2013). Multiple intelligences and leadership. Mahwah, NJ: Lawrence Erlbaum Associates.

Spillane, J. (2008). Leading and managing educational change: Engaging the challenge in practice. Presentation at NCCA Conference, October 2008.

Spreitzer, G., Sutcliffe, K., Dutton, J., Sonenshein, S., \& Grant, A. (2005). A socially embedded model of thriving at work. Organization Science, 16(5), 537-549. http://dx.doi.org/10.1287/orsc.1050.0153

West-Burnham, J. (2009). Developing outstanding leaders: Professional life histories of outstanding headteachers. Nottingham: NCSL.

Yacoub, S. (2000). School prinicipalship in Lebanon: Problems and suggested solutions [In Arabic]. Lebanese Association for Educational Studies, 1(5), 295-330. 
Ghamrawi, N. 